This article was downloaded by: [Faith Armitage]

On: 11 June 2013, At: 14:17

Publisher: Routledge

Informa Ltd Registered in England and Wales Registered Number: 1072954

Registered office: Mortimer House, 37-41 Mortimer Street, London W1T 3J H, UK

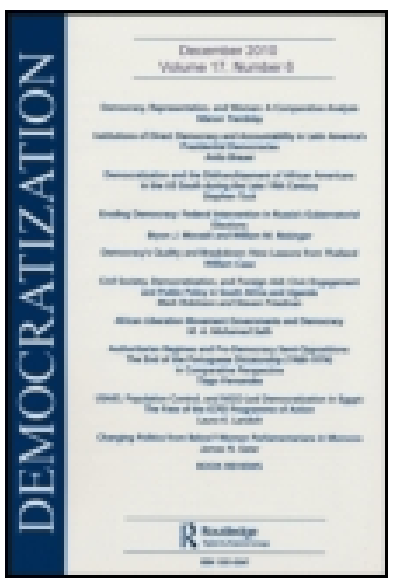

\title{
Democratization
}

Publication details, including instructions for authors and subscription information:

http:/ / www. tandfonline.com/loi/ fdem20

\section{Peace and quiet in the British House of Commons, 1990-2010}

\author{
Faith Armitage ${ }^{\text {a }}$ \\ a Politics Department, Birkbeck College, University of \\ London, London, UK
}

To cite this article: Faith Armitage (2013): Peace and quiet in the British House of Commons, 1990-2010, Democratization, 20:3, 456-477

To link to this article: http:/ / dx.doi.org/ 10.1080/ 13510347.2013.786545

\section{PLEASE SCROLL DOWN FOR ARTICLE}

Full terms and conditions of use: http://www.tandfonline.com/page/termsand-conditions

This article may be used for research, teaching, and private study purposes. Any substantial or systematic reproduction, redistribution, reselling, loan, sublicensing, systematic supply, or distribution in any form to anyone is expressly forbidden.

The publisher does not give any warranty express or implied or make any representation that the contents will be complete or accurate or up to date. The accuracy of any instructions, formulae, and drug doses should be independently verified with primary sources. The publisher shall not be liable for any loss, actions, claims, proceedings, demand, or costs or damages whatsoever or howsoever caused arising directly or indirectly in connection with or arising out of the use of this material. 


\title{
Peace and quiet in the British House of Commons, 1990-2010
}

\author{
Faith Armitage*, \\ Politics Department, Birkbeck College, University of London, London, UK \\ (Received 18 October 2011; final version received 20 February 2013)

\begin{abstract}
This article is concerned with disruption by Members of Parliament in the British House of Commons between 1990 and 2010. Disorder in the "Thatcherite" parliaments of the 1980s has been the subject of parliamentary and academic investigation, but the phenomenon since then has gone unexamined. This article introduces a distinction between nontolerated and tolerated disorder. Non-tolerated disorder has been relatively rare in the House of Commons between 1990 and 2010, and can mainly be attributed to a handful of parliamentary "mavericks". Tolerated disorder, which forms an accepted part of the Commons' culture, is also explored, and recent changes to the House are examined for their potential effects on the phenomenon. While opinions vary about the desirability of tolerated disorder, this article accepts the argument that it is a symptom of serious problems with the British governing tradition and will persist unless and
\end{abstract} \\ until those problems are addressed.
}

Keywords: legislatures; disorder; rebellion; political behaviour; parties

...you must remember that here are phlegmatic Englishman and dour Scots. The "Celtic fringe" is too small to change the atmosphere, especially since the Irish went to enliven their own assembly in Dublin. Scenes are rare. There is no banging of desks; there are no desks to bang; and they would not be banged if there were. The moments of excitement are so rare that they go down in the political annals... The truth is that the House is rarely exciting; usually it is deadly dull. ${ }^{1}$

\section{Introduction}

This article is concerned with the incidence and significance of disruption by Members of Parliament (MPs) in the House of Commons chamber, that is, with conduct that arises "directly or indirectly from parliamentary proceedings, and not with such matters as outside interests, ethical standards, or financial probity, which could lay a Member open to penal sanctions by the House". 2 The focus is on disorder occurring between 1990 and 2010. While disorder in the "Thatcherite" parliaments of the 1980s has been the subject of parliamentary and academic investigation, ${ }^{3}$ to my knowledge, no one has sought to quantify, characterize or explain

*Email: faith.armitage@gmail.com

${ }^{\dagger}$ Current address: Independent Researcher, 103 Benhill Road, London SE5 7LZ. 
parliamentary disorder (or, perhaps more appropriately, its absence) in the 1990s and 2000s.

Previous studies of disorder in the Commons had a straightforward question to answer. As David Judge puts it: "Persistent disorder in the British House of Commons during the premiership of Mrs Thatcher prompted the question 'what's wrong here?"'. ${ }^{4}$ Our question is not as straightforward because the level of disruption since the Thatcher era has varied. Even if it is not clear today that anything is "wrong", we still need to reconcile the classic portrait of the chamber described in the epigraph, which emphasizes the famous British reserve, with more contemporary perceptions of the Commons as a rowdy arena of "yah-boo" politics. A distinction between tolerated and non-tolerated disorder, shown in Figure 1 below and employed throughout, facilitates this reconciliation.

Non-tolerated disruption by definition leads to formal punishment, whereas tolerated disruption does not. ${ }^{5}$ This article is interested in both types, but they must be approached differently. Official statistics are kept by the House on non-tolerated individual and collective disruption. The second and third sections present and discuss, respectively, these statistics for 1990-2010. Briefly to anticipate the main findings, a small handful of "maverick" MPs is responsible for most individual incidents. Both individual and collective non-tolerated disruptions are relatively rare, and do not seem to relate to the much more prominent parliamentary behaviour of "rebellion". It is argued that this official peace and quiet arises because of generic reasons to do with the culture of the Commons and the parties' histories, as well as reasons specific to the Conservative Party which was in opposition for most of the period analysed and therefore, in keeping with what comparative research on parliamentary disorder has shown, ${ }^{6}$ should have been responsible for most disorder. As we will see, it was not.

The fourth and fifth sections present and discuss the phenomenon of tolerated disruption by MPs between 1990 and 2010. Because it goes formally unpunished, no official statistical records of tolerated disorder are kept. Our approach must

\begin{tabular}{|l|l|}
\hline $\begin{array}{l}\text { Non-tolerated individual disruption } \\
\text { e.g. disorder by MPs that leads to formal } \\
\text { punishment by the Speaker using the } \\
\text { powers contained in Standing Orders }\end{array}$ & $\begin{array}{l}\text { Tolerated individual disruption } \\
\text { e.g. barracking or heckling by one MP } \\
\text { 'from a sedentary position' (i.e. sitting on } \\
\text { the benches) of the MP who has the floor }\end{array}$ \\
\hline $\begin{array}{l}\text { Non-tolerated collective disruption } \\
\text { e.g. when there is 'grave disorder' in the } \\
\text { chamber, causing the Speaker to suspend or } \\
\text { adjourn the sitting }\end{array}$ & $\begin{array}{l}\text { Tolerated collective disruption } \\
\text { e.g. collective barracking by groups of } \\
\text { MPs, as is often seen during Prime } \\
\text { Minister's Questions, of the MP who has } \\
\text { the floor }\end{array}$ \\
\hline
\end{tabular}

Figure 1. Distinguishing types of disruption. 
therefore be anecdotal, and the fourth section thus presents anecdotal and more general inductive observations about this type of disruption between 1990 and 2010. The fifth section distinguishes three camps of opinion on the Commons' culture of rowdiness extant in the literature. The article concludes by arguing that in many ways, tolerated disruption is the most serious type in the Commons, both intrinsically - because when it is not simply childish and absurd, it is actually vicious, cruel, sexist, classist, and bullying - and symbolically - because it is an expression or side-effect of the weakness, even the pointlessness, of the House.

An outline of sanctions for disorder in the chamber is necessary before turning to its incidence in the next section. The term "chair" is used here to mean the Speaker and Deputy Speakers, who hold the same disciplinary powers whilst in the chair. The chair has recourse to an escalating scale of sanctions that may be applied immediately. Under Standing Order $43,{ }^{7}$ the Speaker can order any Member whose conduct is "grossly disorderly" to withdraw from the House for the remainder of that day's sitting. A more severe sanction is called "naming" a Member and is set out in Standing Order 44. The chair might resort to this measure if the Member repeatedly refuses to obey the chair's order to withdraw. Alternatively, the chair might immediately "name" a Member if their conduct is "so outrageous to the House's dignity to deserve it", ${ }^{8}$ such as picking up the mace or assaulting another Member. Once the chair has named a Member, a government minister moves a motion to suspend the offender. These motions are invariably agreed (though they sometimes proceed to a vote, or what is known as a "division" in the Commons), and once agreed, the Member is automatically suspended for five sitting days from the service of the House. While suspended, MPs may not sit, vote or speak in the House or in committees, and they are docked five days' salary. ${ }^{9}$

Standing Orders 43 and 44 are designed to deal with disruption caused by one, two or several MPs, rather than large groups. When the disruption is more general, Standing Orders allow the chair to adjourn the House or suspend the sitting, under SO 46. The House's Standing Orders thus equip the chair with several gradations of sanctions to discipline unruly Members which are used with great reluctance. Chairs will typically attempt to dispel the situation by inviting the Member to withdraw the offending remark or moderate their behaviour before imposing a formal sanction.

\section{Statistical picture of non-tolerated disruption}

The context for 1990-2010 is provided by the so-called "frustration" parliaments of the 1980 s. $^{10}$ The parliaments of 1979,1983 and 1987 saw a sharp rise in both tolerated and non-tolerated disorder. The House witnessed many scenes of commotion as opposition MPs, particularly Labour, clashed with Tory MPs. Some of these scenes were fuelled by "the emergence of apparently organized barracking from the government benches" ${ }^{\prime 11}$ with the intention of silencing frontbench MPs from 
the Official Opposition party. Other scenes were fuelled by in-fighting between hard-left Labour MPs, on one hand, and the more moderate Labour leadership and MPs in the newly formed Social Democratic Party, on the other. ${ }^{12}$ Judge argues that the root cause of disorder was the breakdown of the post-war consensus and the increased ideological polarization in the country under Thatcher's New Right government. Class tensions were heightened in the country, and then reflected in the Commons. Hard-left Labour MPs recognized the "anaesthetizing impact" of parliamentary procedure and the "tokenism" of the opposition permitted them by those procedures, and so they deliberately decided to flout the rules in order to articulate the fundamental ideological differences between them and the neo-liberal, neo-conservative government. ${ }^{13}$ To bolster his argument about the 1980 s' parliaments, Judge draws parallels with the 1920s, which also saw relatively high rates of parliamentary disorder against a backdrop of economic crisis and rising class tensions.

We can now turn our attention to the last two decades. ${ }^{14}$

Looking at Table 1, the numbers suggest that between 1990 and 2010, the level of disruption in the House has varied quite considerably. Chairs did not once use their disciplinary powers in the Parliament of 1997-2001, meaning it was - on this measure - the quietest since the 1966-1970 Parliament. However, these powers were used three and seven times, respectively, in the Parliaments of 2001-2005 and 2005-2010, which excepting the "frustration parliaments" of the Thatcher era, were the highest totals since 1945-1950.

Considered against the backdrop of the parliaments of the 1980s only - the short view - things appear to have calmed down. On the long view, stretching back to the 1920s, things appear to have become more disorderly. There have been fewer disruptions, but the level is noticeably higher than the pre-1980s figures. The first decade of the twenty-first century saw the highest total number, excluding the Thatcher era, since the 1920s (Table 2). The "frustration" parliaments perhaps set a new threshold, a "new normal".

Between 1990 and 2010, 13 separate incidents of disruption, leading to the formal disciplining of an individual MP, occurred in the House of Commons chamber. ${ }^{15}$ Two MPs were sanctioned more than once in this period, meaning that just nine individual MPs account for the 13 incidents. Table 3 briefly describes each incident.

Consistent with patterns seen in other legislatures, non-tolerated disorder in the House of Commons emanates mainly from opposition parties, with 10 of the incidents "committed" by opposition MPs and three by MPs in the governing party (Dennis Skinner in 2005 and 2006; John McDonnell in 2009). Four of the incidents involved MPs with frontbench or spokesperson roles, ${ }^{16}$ and the rest involved backbench MPs. Nine of the incidents involved MPs from one of the three main parties (Labour, Conservative and Liberal Democrat), and four from one of the minor parties. None of the incidents involved violence, although one involved a physical demonstration (John McDonnell picked up the mace in 2009); the rest were verbal confrontations only. Men were the main "offenders", accounting for all but one of the incidents. 
Table $1 . \quad$ Use of disciplinary powers SO 43 and SO 44, 1945-2010, by parliament.

\begin{tabular}{|c|c|c|c|c|c|c|c|c|c|c|c|c|c|c|c|c|}
\hline & $\begin{array}{c}1945- \\
1950\end{array}$ & $\begin{array}{c}1950- \\
1951\end{array}$ & $\begin{array}{c}1951- \\
1955\end{array}$ & $\begin{array}{c}1955- \\
1959\end{array}$ & $\begin{array}{c}1959- \\
1964\end{array}$ & $\begin{array}{c}1964- \\
1966\end{array}$ & $\begin{array}{c}1966- \\
1970\end{array}$ & $\begin{array}{c}1970- \\
1974\end{array}$ & $\begin{array}{c}1974- \\
1979\end{array}$ & $\begin{array}{c}1979- \\
1983\end{array}$ & $\begin{array}{c}1983- \\
1987\end{array}$ & $\begin{array}{c}1987- \\
1992\end{array}$ & $\begin{array}{c}1992- \\
1997\end{array}$ & $\begin{array}{c}1997- \\
2001\end{array}$ & $\begin{array}{c}2001- \\
2005\end{array}$ & $\begin{array}{r}2005 \\
2010\end{array}$ \\
\hline SO 43 & 4 & 2 & 0 & 0 & 0 & 0 & 0 & 1 & 2 & 7 & 4 & 14 & 5 & 0 & 3 & 5 \\
\hline SO 44 & 1 & 0 & 2 & 0 & 0 & 0 & 1 & 1 & 0 & 7 & 5 & 12 & 1 & 0 & 0 & 2 \\
\hline Total & 5 & 2 & 2 & 1 & 0 & 0 & 0 & 2 & 2 & 14 & 9 & 26 & 6 & 0 & 3 & 7 \\
\hline
\end{tabular}

Table 2. Use of disciplinary powers SO 43 and SO 44, by decade.

\begin{tabular}{lccc}
\hline Decade & SO 43 & SO 44 & Total \\
\hline $1920 \mathrm{~s}$ & 9 & 11 & 20 \\
$1930 \mathrm{~s}$ & 0 & 5 & 5 \\
$1940 \mathrm{~s}$ & 4 & 1 & 5 \\
$1950 \mathrm{~s}$ & 1 & 2 & 3 \\
$1960 \mathrm{~s}$ & 0 & 1 & 1 \\
$1970 \mathrm{~s}$ & 4 & 1 & 5 \\
$1980 \mathrm{~s}$ & 10 & 18 & 47 \\
$1990 \mathrm{~s}$ & 5 & 1 & 8 \\
$2000 \mathrm{~s}$ & 8 & 2 & 10 \\
\hline
\end{tabular}


Table 3. Members withdrawn or suspended, 1990-2010.

\begin{tabular}{llll}
\hline $\begin{array}{l}\text { Session and } \\
\text { dates }\end{array}$ & $\begin{array}{l}\text { Journal } \\
\text { vol./p. }\end{array}$ & $\begin{array}{l}\text { Hansard } \\
\text { vol./col. }\end{array}$ & Member
\end{tabular}$\quad$ Procedure and reason for withdrawal/suspension

$1992-1993$

2 July 1992

$249 / 130 \quad 210 / 956-7$

Dennis Skinner

SO 43: Oral PQs to Minister for Agriculture, Fisheries and Food (John Gummer).

Skinner refers to minister as a "wart" and a "little squirt" for his putative failure to address a concern about levels of dioxins in his constituency. Repeatedly refuses to withdraw the remarks.

$1993-1994$

29 November

1993

$250 / 25-233 / 789-93$

Rev. Ian Paisley (DUP)

3 March 1994

$238 / 1077-8$

1994-1995

26 January 1995

$251 / 122$

$253 / 471$

\section{Dale Campbell-} Savours (Lab)

9 May 1995

$251 / 322$

$259 / 574-5$

Dennis Skinner

(Lab)

2004-2005

16 December

2004
$261 / 61$

$428 / 1806$
Annabelle Ewing (SNP)
SOs 43 and 44: Min. Statement by SoS for Northern Ireland (Sir Patrick Mayhew). Mayhew discloses that government had secretly been exchanging messages with IRA leaders through a third party. Paisley accuses the SoS, officials and Number 10 of telling falsehoods about those exchanges. Paisley defies Speaker's request to withdraw; is named and subsequently withdraws.

SO 43: Business Qs to Leader of House (Tony Newton). Campbell-Savours asks for debate on government right-to-buy policy, and accuses Con backbencher Alan Duncan MP of "ripping off" taxpayers by buying a council house. Refuses to withdraw term.

SO 43: PMQs (John Major). Campbell-Savours raises allegations about Lord Jeffrey Archer's insider dealing, and asks if there will be review of law since it is "quite clear that it is utterly impossible successfully to prosecute what we all know to be criminal activity". Speaker warns he must not use language that associates the House with his statement, and asks him to withdraw or rephrase his comments; he refuses.

SO 43: Min. Statement by SoS for Trade and Industry (Michael Heseltine). Heseltine announces privatization of some nuclear power stations. Skinner asks Heseltine if he will guarantee that "he will not do the same trick as he pulled with the coal industry and organize a shabby deal with one of his Tory friends, as he did when he sold the coal industry to R.J. Budge? Will he guarantee that this time he will not engage in a crooked deal...?". Refuses to withdraw or rephrase comments.
SO 43: Min. Statement by Defence Secretary (Geoff Hoon). Hoon announces changes to infantry structure. Ewing calls him a "back-stabbing coward" for ending the Scottish 
Table 3. Continued.

\begin{tabular}{|c|c|c|c|c|}
\hline $\begin{array}{l}\text { Session and } \\
\text { dates }\end{array}$ & \multicolumn{2}{|c|}{$\begin{array}{cl}\text { Journal } & \text { Hansard } \\
\text { vol./p. } & \text { vol./col. }\end{array}$} & Member & Procedure and reason for withdrawal/suspension \\
\hline
\end{tabular}

17 March 2005 261/267 432/411 Adam Price (PC)

24 March 2005

8 December

2005

20 April 2006

$262 / 574$

$445 / 229$

2006-2007

23 July 2007 (Con)

Dennis Skinner

(Lab)
263/525-26 463/610-27 George Galloway

(Respect) regimental system (including Black Watch in her constituency, just back from Iraq). Refuses to withdraw the term.

SO 43: Business Qs to LoH (Peter Hain). Price: "Tomorrow is the second anniversary of the vote on the war in Iraq. A motion of impeachment is before us, and there is compelling evidence that the Prime Minister misled the House in taking us to war. Is it not high time that we held him to account_-". Refuses to withdraw remark. [Members must not accuse other Members of deliberately misleading the House.]

Laurence Robertson SO 43: Oral PQs to Min. for Children, Young People and Families (Margaret Hodge). In reply to an earlier question, Hodge had given figures for the number of special schools closed since 1997. Robertson accuses her of dishonesty and misleading the House about which schools are to close because she did not mention the closure of two schools in his constituency, which had been announced that morning. Refuses to withdraw remark.

SO 43: Oral PQs to Chief Sect. to Treasury (Des Browne) about the British economy. George Osborne suggests the Treasury made over-optimistic predictions about economic performance before the election. Picking up on the figures for growth announced by Browne, Skinner asks: "Is my right hon. Friend aware that in the 1970s and a lot of the 1980s, we would have thanked our lucky stars in the coalfield areas for growth of $1.75 \%$ ? The only thing growing then were the lines of coke in front of boy George and the rest of them". Refuses to withdraw remark.

Dennis Skinner SO 43: Business Qs to LoH (Geoff Hoon). Skinner accuses Dep. Speaker Alan

(Lab) Haselhurst (Con) of favouritism towards Tories, specifically Theresa May, who was questioning Hoon about statements by the PM and said the PM had misled the House. Hoon offered to give May a chance to withdraw the remark. Dep. Speaker said May had not suggested PM had deliberately misled House. Skinner: "She has been let off because she is a Tory", and "Why is there one rule for Labour and another for Tories?" Dep. Speaker: "Order. I name the hon. member. I see that by withdrawing from the Chamber, the hon. member has taken the easier way out".

SOs 43 and 44: Debate on report by Standards and Privileges Committee which recommended suspending Galloway from the House for 18 days following an 
2007-2008

26 February

2008

$2008-2009$

15 January 2009
$264 / 217 \quad 472 / 922-6$

Ed Davey

(Lib Dem)

486

John McDonnell

(Lab) investigation by the Parliamentary Commissioner for Standards which concluded that Galloway had breached the House's code of conduct in several ways (e.g. failing to register a financial interest and use of taxpayer-funded facilities for his charity, the Mariam Appeal). The debate was always going to lead to Galloway's suspension from the House, but the Speaker ejects him from the chamber about an hour into the debate when Galloway, despite many warnings, persists in straying off topic of the report itself to develop complaints and conspiracies about the House, the Committee, the

Commissioner, and others.

SO 43: Points of order following selection of amendments for debate on Treaty of Lisbon bill. A Lib Dem amendment for a referendum on UK's membership of EU was not selected by the Speaker. Davey persisted in making points of order. After his ejection, Lib Dem MPs walked out of the chamber.

SOs 43 and 44: Min. statement by SoS for Transport (Geoff Hoon). Hoon makes a number of announcements about transport infrastructure, including announcement of approval for 3rd runway at Heathrow. McDonnell asks if there will be a vote in the House on the issue. Hoon says no. McDonnell leaves his seat and picks up the mace before placing it on a front bench. Dep. Speaker names the Member and the motion is passed without a vote. McDonnell withdraws.

Note: There are no entries in this table for sessions in which the chairs did not have recourse to their formal disciplinary powers.

Table 4. Use of disciplinary power so 46, 1945-2010, by parliament.

\begin{tabular}{ccccccccccccccccc}
\hline $\begin{array}{r}1945- \\
1950\end{array}$ & $\begin{array}{r}1950- \\
1951\end{array}$ & $\begin{array}{r}1951- \\
1955\end{array}$ & $\begin{array}{r}1955- \\
1959\end{array}$ & $\begin{array}{r}1959- \\
1964\end{array}$ & $\begin{array}{r}1964- \\
1966\end{array}$ & $\begin{array}{r}1966- \\
1970\end{array}$ & $\begin{array}{r}1970- \\
1974\end{array}$ & $\begin{array}{r}1974- \\
1979\end{array}$ & $\begin{array}{r}1979- \\
1983\end{array}$ & $\begin{array}{r}1983- \\
1987\end{array}$ & $\begin{array}{r}1987- \\
1992\end{array}$ & $\begin{array}{r}1992- \\
1997\end{array}$ & $\begin{array}{r}1997- \\
2001\end{array}$ & $\begin{array}{r}2001- \\
2005\end{array}$ & $\begin{array}{r}2005- \\
2010\end{array}$ \\
\hline SO46 & 0 & 0 & 0 & 1 & 2 & 0 & 0 & 3 & 3 & 3 & 4 & $2^{\mathrm{a}}$ & $2^{\mathrm{b}}$ & 0 & 0 & 0
\end{tabular}

Notes: 'Both incidents occurred in the 1989-1990 session, so are not discussed in this article. See Judge ("Disorder in the 'Frustration' Parliaments"). 'These incidents occurred on the same day, within five minutes of each other. 
In a classic study of roles taken up by MPs at Westminster, Donald Searing identified the "maverick". ${ }^{17}$ Maverick MPs tend to be ideological hardliners, show independence from or impatience with authority, and are therefore more immune than other types of MPs to their party whips' carrots and sticks. ${ }^{18}$ It is perhaps unsurprising to observe that of the nine individuals who were sanctioned for disorder, five (Skinner, Paisley, Campbell-Savours, Galloway and McDonnell) can be regarded as parliamentary "mavericks", as assessed by their entries in (successive editions of, where appropriate) The Almanac of British Politics.

Maverick behaviour usually entails rebellious behaviour, whereas the reverse is not true. "Rebellious behaviour" refers to when MPs vote against their party whip. ${ }^{19}$ Skinner and McDonnell, for example, are amongst the most rebellious MPs in their party. ${ }^{20}$ Rebelliousness has become widespread and common in the House of Commons in the last 20 years. $^{21}$ For example, more than half of Labour MPs in the 2001-2005 Parliament defied the whip at least once, and there were rebellions by Labour MPs in just over one-fifth of all votes. ${ }^{22}$ In the same parliament, $45 \%$ of Conservative MPs defied the party whip, but at about half the rate of Labour MPs. ${ }^{23}$ Yet the low numbers of MPs being officially sanctioned by the chair makes it clear that the vast majority of rebels in all parties seem able to restrain themselves from the kind of disruption that leads to ejection from the chamber. Analysts have suggested that rebelliousness in the Commons can be habit-forming: once an MP has defied the whip, and thus reduced his or her chances of preferment, there is less stopping them from doing it again. Continuing with the drugs analogy, we can say that rebelliousness in voting behaviour is not a "gateway" to disruptiveness. They are very different kinds of legislative behaviour.

Turning to collective non-tolerated disruption, in the last 20 years, there has been only one occasion where the chair suspended the House due to "grave disorder", under SO 46, as Table 4 shows.

This incident fell outside the timeframe of Judge's research, but it is clearly part of the era of "frustration" parliaments that he studied. The English MP-dominated Conservative Government flouted an established parliamentary convention by choosing to announce a controversial policy change affecting Scottish constituencies by issuing a written answer to a question rather than through a formal announcement by a Minister to the Commons. This breach evidently emboldened Scottish Labour backbench MPs to ignore rules about parliamentary decorum, and a group gathered in the well of the House in front of the mace to show their displeasure. $^{24}$

The key point for this analysis is that for almost 20 years, no chair has felt that the level of collective disorder has been so grave as to make it necessary to suspend or adjourn proceedings. All three parliaments under the New Labour government including the one dominated by the Iraq war - were, on this measure, "peaceful", although heated debates, large-scale rebellion by backbench government MPs, and ministerial resignations over the war provide alternative indicators of parliamentary mood. Whilst it is beyond the scope of this article, it is interesting to speculate on what connections there may be between "peace" inside the House, such as when 
the Conservatives in opposition supported the Labour government's decision to go to war in Iraq, and the levels of protest and disruption outside of it, such as the million-strong march by the British public against the war. ${ }^{25}$

\section{Playing by the parliamentary rules I: why official peace and quiet reigned}

Like other parliaments, Westminster's history includes periods of organized campaigns of deliberate disorder by legislative minorities - such as the obstruction by Irish Nationalist MPs in the 1880s. But compared to this period, as well as the Thatcher era, the last 20 years in the Commons have seen low levels of non-tolerated disorder by individuals and groups. Why? The literature offers three answers, two of which help to explain the situation in a "generic" way - that is, regardless of which parties are in government and opposition. The third answer is specific to the Conservative party, which was in opposition for 13 of the 20 years considered (1997-2010), and thus in theory should have been the source for most parliamentary disruption.

The first and most obvious answer relates to the degree of ideological polarization in Britain. If, as Judge argues, polarization produced disruption, then peace and quiet in the Commons could be a reflection of its opposite: ideological consensus. Analysts disagree about whether ideological "consensus" or "convergence" is the better term, but generally agree that, post-war, and during the post-Thatcher era in particular, there has seen a coincidence of ideas and policies amongst Britain's main political parties. ${ }^{26}$ Observers have noted the change this has made during election campaigns, where instead of articulating big ideas and visions, parties have competed in a bland, technocratic and managerial form of politics. It is not unreasonable to think the change also affects politics in the chamber after elections. And, whilst not necessarily an issue of ideology, the Official Opposition's support for what was arguably New Labour's most controversial policy in 13 years of government - that is, the decision to go to war in Iraq - also reduced the scope for disorder.

The second answer relates to the nature of the main parties represented in the contemporary Commons. As Philip Norton puts it, they are "constitutional" parties whose Members are "constrained by a belief system" about "the propriety of obedience" to the rules of the House. ${ }^{27}$ From the leaders to the rank and file, this has arguably always been true for the Conservative party, and would help to explain why there was just one Tory MP amongst the individual "offenders" in the last 20 years and why he was required to apologize. Within the parliamentary Labour party, respect for and adherence to the rules traditionally has been more uneven. In the period of Labour opposition analysed by Judge, it was mainly hard-left backbenchers who felt that the "niceties of parliamentary procedure must give way to the right of Members to articulate the grievances of their constituencies". However, "most leaders" of the Labour Party, he continues, were "constitutional conservatives" who accepted the "aristocratic embrace" of the Commons and obeyed parliamentary rules to the same extent as Conservatives. ${ }^{28}$ 
In other words, in the 1980s and earlier, Labour's leaders already accepted the need for the party to be a constitutional party. And as the years of Conservative rule mounted, it would be understandable if this mentality spread to those on the Labour backbenches as well as those hoping to enter parliament as a Labour MP. New Labour's election victory in 1997 was preceded by a sustained campaign to bring backbenchers under control, to minimize dissent and rebellion. ${ }^{29}$ Their docility after the electoral landslide of 1997 was much remarked upon. The willingness to play by the parliamentary rules long exhibited by Labour's leaders appears to have permeated throughout the party's ranks in the last 20 years, save for a handful of "mavericks" immune to both carrots and sticks wielded by their whips.

The third, Conservative-specific, answer in the literature relates to the party's structures and outlook. The modern parliamentary Conservative party is highly organized and structured. It has a complex network of subject committees, backbench MPs' committees, and informal groupings such as dinner clubs. ${ }^{30}$ This infrastructure makes it possible for the party's managers closely to monitor MPs, so that they are aware of and can take steps about frustration and unrest. According to Norton, a "whip attends each meeting [of subject committees] and any criticisms are reported to the minister and the Chief Whip". ${ }^{31}$ Norton suggests that this system is at least partly responsible for the success of the Conservative Party whilst in government since it provides effective ways to address dissent within the party. Presumably, the same general functions of the system - that is, providing awareness of and communication with any potential trouble-makers - also obtain when the party is in opposition, and to the same effect. "Party committees have provided the means for dissent to be fanned but more often to be absorbed". 32 In terms of a collective party outlook or mindset, the dominance of the Conservative Party as the governing party in Britain over the last century suggests another reason for its general adherence to the rules: it was secure in the knowledge that it would eventually form the government again. Such a conviction means that the Tories can be "good losers" 33 whilst in opposition, and are content with expressing their objections in ways legitimately open to opposition parties rather than by rule-breaking.

\section{Anecdotal picture of tolerated disruption, 1990-2010}

The House of Commons can be a very rowdy place, particularly - though not only - at Prime Minister's Questions (PMQs) when the chamber is over-filled with MPs primed to "lob custard pies at each other". ${ }^{34}$ The following description is of PMQs on 10 December 2008, a typical session. There are massed ranks of MPs shouting and hooting at the top of their lungs, waving their arms and order papers about, with the Speaker attempting to restore calm. The Tory benches erupt when Prime Minister Gordon Brown makes a slip of the tongue and refers to his government "saving the world" when he means "saving the banks". Later, an earnest question by Nick Clegg, the leader of the third party, about a "single mum who came to see 
me" provides the excuse MPs needed to pile in on him with sexual innuendo-laden heckling arising from an ill-judged comment about how many women he'd slept with which had been published earlier as part of a magazine profile. ${ }^{35}$ Even Clegg's own colleagues struggle to look serious. Still later, a question from a female Labour backbencher about the regulation of lap-dancing clubs is met with more lewd chuntering from around the chamber. ${ }^{36}$

There is some evidence to suggest that the House has grown increasingly rowdy since 1979. Bates et al. measured rowdiness by counting the number of times that [Interruption] appears in Hansard transcripts during a sample of PMQs for the last five prime ministers, from Margaret Thatcher to David Cameron. ${ }^{37}$ This showed that the average number of interruptions per session has increased from less than one during Thatcher's premiership to about 6.5 during Cameron's. Tolerated disorder can and does occur any time the House is sitting and not only during PMQs, so a comprehensive quantitative analysis of [Interruptions] would need to be carried out before we could know whether Bates et al.'s PMQs rowdiness finding generalizes to the entirety of Commons debates, not just PMQs, in recent decades. This would be an interesting line of future research but is beyond the scope of this article. ${ }^{38}$ The focus here is on exploring the nature of tolerated disruption between 1990 and 2010, and distinguishing three camps of opinion about what such disruption is for.

There are regular events in the Commons' weekly timetable that are especially prone to outbreaks of tolerated disruption, even if the specific scheduling of these moments has been subject to change. Prime Minister's Questions - an "ordeal by bellowing" 39 or "scrutiny by screech" springs to mind, but it is not the only one. Until 1998, when the Commons changed its sitting hours and reduced the number of late-night sittings, Thursday nights were often equally rowdy. According to long-time Westminster journalist Chris Moncrieff: "Invariably there was a big debate and a raucous wind-up session... with many MPs noisy and exuberant in a matter which suggested prolonged attendance in the Strangers' Bar during the evening". ${ }^{41}$ The changes to sitting hours since 1998 have been said to reduce the amount of time that MPs spend drinking in the bars, and consequently, to have reduced the rowdiness. ${ }^{42}$

The breakdown of behind-the-scenes channels of communication between parties has been shown to be an important factor in the levels of disruption (both tolerated and non-tolerated) in legislatures. ${ }^{43}$ Westminster is no exception to this, and one of the customs it has evolved to help grease the wheels of legislative business is the practise of pairing. This is when two members on opposite sides of the House agree not to vote in particular divisions so as to cancel each other's absence out. The suspension of pairing arrangements is a sign that relations between the parties have broken down, and can lead to heightened tensions in the chamber with MPs forced to spend even longer hours at Westminster than normal. This happens from time to time in the Commons, and one episode occurred between 1992 and 1994 during the Maastricht/European debates. ${ }^{44}$ 
Television broadcasting of proceedings in the main chamber was introduced in the Commons in November 1989 with many misgivings about the effect on MPs' behaviour. ${ }^{45}$ Speaker George Thomas observed that radio broadcasting, introduced on a permanent basis in 1978, had brought a "new aggressiveness" to proceedings, ${ }^{46}$ and there was concern that the television cameras would have a similar effect. A study published a year after the introduction of television broadcasting concluded that it had had no ill effect on MPs' behaviour. ${ }^{47}$ This may have been too soon to establish any changes, and, as far as I know, there have been no other academic studies on the question since then. Nearly 20 years after television's introduction, Moncrieff argues that the fears it would encourage "grandstanding, drama queens, ham-acting and general histrionics" have been partly justified. $^{48}$

Whether a force for good, bad or indifferent behaviour, television broadcasting at least gets credit for being the source of a new behaviour: donutting, which is when MPs form a circle around their colleague who has the floor. There are televisual reasons for doing this; for example, "to suggest to the innocent viewer that a crowded House is all agog with what the speaker is saying". " But it is also apparently used as a protective device against barracking. For example, successive leaders of the Liberal Democrat party have been a target of persistent barracking by Labour and Conservative MPs. According to one retired senior clerk: "The Lib Dems countered by putting a donut around Clegg so he was to some extent insulated from the noise". 50 Female MPs have also used "donuts" to try to protect other women. ${ }^{51}$

The reference to female MPs highlights a significant new development in the Commons in the 1990-2010 period: namely, the arrival of women in numbers to the chamber. The 1997 general election, which produced a landslide for New Labour, also saw a record number of women returned. Overnight, the number of female MPs doubled from 60 to 120 , or $18.2 \%$ of the Commons. New Labour had the highest proportion of women by far, accounting for 101 of the 120 women elected. There is a huge, ongoing debate within the literature on women's political representation about the effects of women's presence, both on legislatures as institutions and on public policy outcomes. Suffice it to say here that plenty of research on women MPs at Westminster points to the view that the influx of women had an impact on the culture of the Commons. Many female MPs argue that they "do" politics differently from men - are more consensual and practical, for example - and that these gender differences extend to conduct in the chamber. ${ }^{52}$ Likewise, at a more popular level, some parliamentary observers have suggested that the increased number of female MPs has meant a quieter chamber. ${ }^{53}$ This goes hand-in-hand with widespread assumptions that men are the main culprits when it comes to being rowdy in the House. In moments when the level of tolerated disruption is likely to be at its highest such as during PMQs - the chamber is frequently described in terms such as "bear pit" and "bun fight" which invoke class-inflected images of masculinity. 
In fact, recent research on MPs' views about PMQs shows that female MPs are more negative about this feature of Commons life than their male counterparts. ${ }^{54}$ Such findings chime with much anecdotal evidence collected by feminist researchers that female MPs, than a group, tend to believe that they are affected differently by the chamber's rowdiness than male MPs, as a group. However, such findings do not gainsay that some individual female MPs enjoy a good barracking as much as some individual male MPs, as the following anecdote suggests. It is from an interview with a former special advisor to two Leaders of the House. He would sometimes watch debates from the bench reserved for civil servants, aides and officials, inside the chamber and close to MPs' benches and the Speaker's chair, and thus in a position to actually hear noise and comments that are inaudible in the public galleries behind glass screens:

GP: Gwyneth Dunwoody was particularly irritating when she was in the Commons because she was, there would be a constant stream of invective directed at somebody under her breath but loud enough for everybody to hear. I don't know how you stamp that out because ... at what point do you say, "okay right, that's too much"? The MPs themselves enjoy it and they're often, you know, very pleased with their own jokes because their mates around them are laughing. I mean it is childish in the extreme when you watch it, and there are certain MPs in particular who are just really trying to make the people around them laugh.

FA: Do you want to name names?

GP: Well you could name 50. People like Stephen Pound who is just constantly... Actually he's one of the funnier MPs. ${ }^{55}$

Thus, whilst there is evidence for a general gender difference in attitudes towards PMQs in particular, it is probably essentialist and over-general to believe that tolerated disruption emanates wholly or mainly from men. In particular, when there is collective rowdy behaviour, particularly "campaigns" organized or encouraged by party whips, it is a safe bet that women as well as men will participate.

In describing the phenomenon of tolerated disruption to this point, images of PMQs have predominated. But it is important to remember that it is not only the "big beasts" of the two main opposing parties who are the targets of barracking in the chamber. Tolerated disorder in the Commons can escalate to what, in other workplaces, would probably be recognized as bullying: that is, where individuals are singled out, isolated and attacked by other Members. The current Speaker, John Bercow, gave this example:

I remember at one time, Conservative Members many years ago, always used to say when Richard Younger-Ross, a slightly unusual Lib Dem member, slightly odd sort of manner, a nice man, but he'd stand up and Conservative members would go in unison: "Ooooh noooo!" Like a tennis match ... collectively it makes a big noise. I think we used to think it was frightfully good fun. I remember Tony Blair looking 
slightly taken aback and saying, "I don't know what the Honourable gentleman has done to upset the Conservatives". And David Maclean as Chief Whip very sensibly said to Conservatives "the behaviour must stop". 56

The heckling of Younger-Ross (MP from 2001 to 2010) was sufficiently noteworthy that it was documented in the Almanac of British Politics, whose authors interpret it as a form of class antagonism:

\begin{abstract}
With his name hyphenated not as evidence of listing in Burke's Landed Gentry, but as a modern acknowledgement of his wife's name in that most perfect union, he has experienced some snobbish Tory barracking in the Commons when rising to address it in his London suburban Pooteresque manner, and rather foolishly responding on one occasion in February 2003 with, "they are so predictable, so predictable!" to a renewed volume of derision. ${ }^{57}$
\end{abstract}

More recently (and perhaps as a one-off rather than the sustained harassment of Younger-Ross) it was reported that backbench Labour MPs had heckled and mocked a Tory MP with cerebral palsy for his disability. ${ }^{58}$

What might have distinguished (if that is the right word) tolerated disorder in the last 20 years from previous eras is the amount of sexist harassment going on. This is not to say that it was altogether new: research shows that the very first women MPs in the House faced extreme hatred and hostility. ${ }^{59}$ If there were sexist over- or undertones to the tolerated disorder in the 1980s, Judge does not mention it. Sexism and misogyny have definitely been features of such disorder, at least since 1997, according to numerous studies by feminist scholars and personal accounts by female MPs. ${ }^{60}$ To take just one example, Sones, Moran, and Lovenduski devote a whole chapter in their book to accounts of sexual harassment experienced in the chamber by women MPs elected to parliament in 1997 (mainly, New Labour women). They note that, "The taunting was so serious on occasions that Dawn [Primarolo] came close to resigning from her seat", and that catcalls and jeers were sometimes accompanied by gestures too: "whenever a Labour woman got up to speak, [some Conservative men] would take their breasts - their imaginary breasts in their hands and wiggle them and say, 'Melons' as we spoke". ${ }^{61}$ It is plausible that in the period focused on here, sexist and misogynist taunting have supplanted earlier forms of class-based heckling as women entered in greater numbers and the composition of the House, in terms of social background, changed. ${ }^{62}$

\title{
Playing by the parliamentary rules II: competing views on tolerated disruption
}

As indicated at the start of this article, non-tolerated disruption in the Commons is a relatively neglected topic, for example, in comparison to the phenomenon of rebellion. However, tolerated disruption, or the culture of barracking and "robust adversarial confrontation" has been documented, described, and analysed by many 
participants and commentators. ${ }^{63}$ From this literature, it is possible to discern three key camps of opinion, one positive and two negative. They offer different answers to the question: "what are barracking and rowdiness for?"

The first camp holds that rowdiness, including at PMQs, is not a problem. It is part of the culture of parliament, and it is better for Westminster to be this way than to be like some European parliaments, where people just read boring speeches into the record and then go home. ${ }^{64}$ According to this view, barracking or tolerated disorder serve at least two purposes. First, it reassures the public that in the Commons there is still a culture of actual debate, with cut and thrust, rather than just a series of politicians reading prepared speeches; in other words, it show the public that their MPs care. Second, it is a test for political leaders or would-be leaders: "the wall of sound that frontbenchers must clamber over to be heard [at PMQs] serves a useful constitutional purpose too...enabling backbench MPs to weed out weak leaders". 65

The second camp takes a dim view of tolerated disruption and the Commons' yah-boo culture on the grounds that it harms democratic representation. This view has been articulated by a recent Procedure Committee, which argued that tolerated disruption is intended

... to deny a fair hearing to a fellow Member. As such [it is] in our view, every bit as subversive of the parliamentary ethos as the more overt disruptions - which they can themselves provoke - which lead to the naming and suspension of individual Members. ${ }^{66}$

Research on women MPs by feminist scholars constitutes a significant strand within this school of thought. This literature has repeatedly demonstrated that women in the Commons believe they adopt a different style of politics to their male counterparts, and that they tend to be put at a disadvantage in a gladiatorial debating chamber. ${ }^{67}$

The third camp does not disagree with the conclusions of the second camp but thinks that it focuses on the symptoms rather than the disease. The disease - the real problem - is the combination of the executive dominance of parliament and rigid party control of MPs that has grown up over many years. This view has been cogently expressed by Tony Wright who argues that critics of "yah-boo" politics are missing the point: "The Commons is like it is because of what it is now for" ${ }^{68}$ It is the arena in which rival parties put on a show of opposing each other whilst underneath, the parties accept the established "governing tradition" of British parliamentary democracy which creates strong majoritarian party-governments entitled to dominate the legislature. ${ }^{69}$ Genuine government accountability is a casualty of such consensus over basic governing arrangements. Parliament is reduced to "heckling a steamroller": "The heckling is loud and raucous, at least from the opposition parties, but the executive steamroller takes it all in its stride and gets on with its governing business". ${ }^{70}$ A by-product of this is a chamber where demanding accountability of the government takes on a ritualistic, theatrical 
quality: "Even the anger is usually synthetic"71 - though I imagine the hurt and humiliation felt by some individuals who have been on the receiving end of attacks is real enough.

\section{Conclusions}

On the face of it, the British Parliament compares favourably to some legislatures, such as the Japanese diet in certain periods, or the Ukranian parliament which descended into mayhem in 2010 with politicians hurling punches, eggs, and smoke bombs at one another and at the Speaker. As a recently retired MP puts it, "although harsh things are sometimes said, we are not actually trying to kill each other. Differences are ultimately resolved at the ballot box" ${ }^{72}$ Parliamentarians at Westminster surely deserve credit for this restraint. But the more extreme clashes seen in other legislatures (and very rarely at Westminster) sometimes express legitimate disagreement over democratic first principles such as the need to respect the rights of opposition parties or the desire to replace a majoritarian governing system with a consensual one. On this view, obedience to the established legislative rules can signal an overly-cosy consensus about ossified constitutional arrangements that have failed to keep pace with a changing democratic society. At the same time, the Commons' tradition of tolerated disorder has been shown to emanate at least partly from parliament's weakness vis-à-vis the executive and party control. For these reasons, and because of the humiliating and discriminatory nature of some tolerated disorder, when British MPs compare their record to that of other, more volatile, legislatures, they shouldn't break their arms patting themselves on the back just because they manage to keep disruption to a "tolerable" level.

\section{Acknowledgements}

I am grateful to David Judge and Neal Razzell who read earlier versions of this article and made perceptive suggestions. Thanks to two anonymous reviewers for this journal who were very supportive of the analysis presented here, as were colleagues in the Politics Department at Birkbeck College. I am also grateful to: Elizabeth Evans at Bristol University; Oonagh Gay, Andrew Kennon, Lynn Gardner and Anne-Marie Griffiths at the House of Commons; and Ruth Fox at the Hansard Society for patiently answering my questions and offering suggestions. Contributions from fellow panellists and participants at APSA 2011in Seattle and the GCRP workshop on Disruptive Democracy held at the University of Warwick in 2010 also helped to shape this article. Any remaining errors or misinterpretations are, of course, my own. I am grateful to the Leverhulme Trust for providing funding for this research.

\section{Notes}

1. Jennings, Parliament, 19-20.

2. HC 290, First Report: Conduct of Members, v. For a recent analysis of ethical misconduct by British parliamentarians, see Allen, "Dishonourable Members?". 
3. HC 290, First Report: Conduct of Members; Judge, "Disorder in the 'Frustration' Parliaments".

4. Judge, "Disorder in the 'Frustration' Parliaments", 532.

5. It could be argued that it would be more precise to use "punished" versus "non-punished" as the key distinction here, on the grounds that Speakers of the House famously (and repeatedly) call for "order, order" and thus seek to calm rowdiness but without punishing MPs. I accept this point, but prefer the tolerated/non-tolerated distinction used here because I wish to convey the sense in which the rowdiness and rudeness that ultimately goes unpunished is a routine, expected part of performance in the House. To be sure, chairs remonstrate with disruptive Members and attempt to rein them in, but seemingly with no real hope or expectation of effecting a permanent change to the established culture of the Commons - hence, tolerated disruption.

6. See, for example, Wolfe, "Creating Democracy's Good Losers".

7. The numbers assigned to the chair's disciplinary powers have changed over time in successive editions of the House's Standing Orders. The current Standing Order (or $\mathrm{SO}$ ) numbers are used here and the data presented have been altered accordingly.

8. Evans, Dod's Handbook, 96.

9. If a Member is named twice in a session, the suspension is automatically for 20 sitting days, with the same consequences. On a third infraction within a session, the Member is automatically suspended for the remainder of the session. This has never happened, but one Member - Ron Brown (Labour) - was suspended for 20 days in 1981 and 1988.

10. Judge, "Disorder in the 'Frustration' Parliaments".

11. Ibid., 541.

12. The Social Democratic Party was formed in 1981 by four senior Labour Party moderates (two of whom were sitting Labour MPs at the time).

13. Judge, "Disorder in the House", 375.

14. The data for these tables comes from three sources: HC 290, First Report: Conduct of Members; Judge "Disorder in the 'Frustration' Parliaments,"; and the House of Commons Journals for 1990 to 2010, with the relevant data compiled by the author. Andrew Kennon, Lynn Gardner, Anne-Marie Griffiths, and Steve Hammett at the House of Commons, and Ruth Fox at the Hansard Society helped locate data, interpret apparent omissions, and supplied anecdotal information.

15. This number is lower than that produced by adding up the numbers in the last four columns of Table 1 because, typically, if the Speaker "names" an MP (i.e. invokes SO 44), he or she will have already tried - and failed - to order them to withdraw (i.e. $\mathrm{SO} 43$ ).

16. This includes George Galloway, who, when he was sanctioned, was the only MP for the Respect Party in the House of Commons. Frontbench and backbench data was derived from House of Commons Library Research Paper 09/31.

17. Searing, Westminster's World, 72-7.

18. Ibid, 74 .

19. See Cowley, Revolts and Rebellions, 12-13, for a discussion.

20. Ibid., 523.

21. The definitive source for data on rebellions is www.revolts.co.uk, a website maintained by Philip Cowley, Mark Stuart and Philip Norton.

22. Cowley and Stuart, "Dissention amongst Labour Party".

23. Cowley and Stuart, "Dave's Dissidents?"

24. For a description of these events, see Boothroyd, Betty Boothroyd, 174-6.

25. Beetham, "Political Participation, Mass Protest".

26. See, for example, Kerr, Post-war British Politics; Hay, Political Economy of New Labour; Wright, British Politics. 
27. Norton, "Playing by the Rules", 29.

28. Judge, "Disorder in the House", 375.

29. Cowley, Revolts and Rebellions, 7.

30. Norton, The Conservative Party.

31. Ibid., 133.

32. Ibid., 139.

33. Wolfe, "Creating Democracy's Good Losers".

34. Wright, British Politics, 83.

35. It was the March 2008 edition of $G Q$ magazine.

36. Footage of this PMQs can be viewed on the internet at: http://www.youtube.com/ watch $?=n g M s \quad 4 I 1$ o\&feature $=m f u$ in order\&list $=U L$.

37. Bates et al., "Questions to the Prime Minister", 12-13.

38. There are limitations to this approach. Hansard - the official report of proceedings in the Commons - is not a full verbatim record of proceedings, and it does not record the volume of noise in the chamber. Various kinds of interjections, from deafening generalized noise to unrepeatable insults are sometimes but not always recorded. To illustrate: in an article for the website www.politics.co.uk, Alex Stevenson describes an exchange between the Speaker and a Conservative MP as he, Stevenson, saw it from a vantage point above the Speaker's chair and compares this to the "official" version: "As usual, the official record presents a soberer version than the reality. While the above was being said, Labour backbenchers were shouting away, roaring 'Sit down!' at Stuart. At one point an opposition MP went further, venturing: 'Sit down, stupid!' Hansard did not record these remarks. Nor did it convey the full extent of Bercow's bile. I would propose they amend their version with this: 'DON'T SHAKE YOUR HEAD AT ME!'” (Stevenson, "Does the Speaker"). Moreover, protocols for recording interruptions may have changed over time, and Hansard reporters may not be consistent in how they apply such protocols.

39. Borthwick, "On the Floor", 72.

40. Bercow, "Speech to Centre for Parliamentary Studies".

41. Moncrief, Wine, Women and Westminster, 79.

42. Cf. Moncrief, Wine, Women and Westminster.

43. Cf. Crowe, "The Web of Authority"; Uslaner, "Comity in Context."

44. Thanks to Ruth Fox for this example.

45. House of Commons Information Office, "Broadcasting proceedings."

46. Thomas, $M r$ Speaker, 185.

47. Hetherington, Weaver and Ryle, Cameras in the Commons.

48. Moncrief, Wine, Women and Westminster, 97.

49. Ibid., 99.

50. Private correspondence.

51. Childs, "Parliamentary Sororal Friendships".

52. Cf. Childs and Cowley, "Too Spineless to Rebel?"

53. BBC World Service Newshour, 2010. Daily Mail sketchwriter Quentin Letts told Newshour that the House had become less rowdy with the increased number of women. He also pointed to the change in sitting hours, which meant less drinking and aggression in the lobbies between male MPs.

54. Lovenduski, "Prime Minister's Questions" 332.

55. Author interview with Greg Power, 4 April 2011.

56. Author interview with Speaker John Bercow, 24 November 2009.

57. Waller and Criddle, An Almanac of British Politics, 922.

58. Daily Mail, February 6, 2011.

59. Cf. Lovenduski, Feminizing Politics, 49. 
60. This list is not exhaustive but see: Childs, New Labour's Women; King, House Music; Lovenduski, Feminizing Politics; McDougall, Westminster Women; Puwar, Space Invaders; and Sones, Moran and Lovenduski, Women in Parliament.

61. Sones, Moran and Lovenduski, Women in Parliament, 67.

62. Cf. Rush, Role of the Member.

63. See citations given in endnote 60. Other examples include Lowther, "Do We Really Hate?"; Radice, Vallance, and Willis, Member of Parliament; Lovenduski, "Prime Minister's Questions"; Boothroyd; Thomas; Wright.

64. This point, comparing Westminster favourably to the European Parliament, was made by three different Conservative MPs to me in interviews conducted between 2009 and 2011.

65. Lowther, "Do We Really Hate".

66. HC 290, First Report: Conduct of Members, xii.

67. See citations given in endnote 60 and 63, and final report and evidence given to Speaker's Conference.

68. Wright, British Politics, 83 (italics in original).

69. Ibid., $12-13,38$.

70. Ibid., 81.

71. Ibid., 87.

72. Mullin, Decline and Fall, 456.

\section{Notes on contributor}

Faith Armitage was a Leverhulme Research Fellow in the Department of Politics, Birkbeck College, London, from 2008-2012. Her research interests include British politics and legislative studies, contemporary normative political theory, feminist political theory, and gender and politics. Her work has appeared in British Politics, the Journal of Legislative Studies, Feminist Theory, and Res Publica: A Journal of Legal and Social Philosophy.

\section{Bibliography}

Allen, N. "Dishonourable Members? Exploring Patterns of Misconduct in the Contemporary House of Commons.” British Politics 6, no. 2 (2011): 210-240.

Bates, S. R., P. Kerr, C. Byrne, and L. Stanley. "Questions to the Prime Minister: A Comparative Study of PMQs From Thatcher to Cameron." Parliamentary Affairs 65 (2012): 1-28, http://pa.oxfordjournals.org/content/early/2012/09/24/pa.gss044.

BBC World Service Newshour, 17 December 2010.

Beetham, D. "Political Participation, Mass Protest and Representative Democracy." Parliamentary Affairs 56, no. 4 (2003): 597-609.

Bercow, J. (2010) "Speech to the Centre for Parliamentary Studies." Accessed January 30, 2013. www.johnbercow.co.uk

Boothroyd, B. Betty Boothroyd: The Autobiography. London: Century, 2001.

Borthwick, R. "On the Floor of the House." In Parliamentary Questions, edited by Mark Franklin and Philip Norton, 73-103. Oxford: Clarendon, 1993.

Childs, S. New Labour's Women MPs:Women Representing Women. London: Routledge, 2004.

Childs, S. "Parliamentary Sororal Friendships: When New Labour Women are Under Attack." Paper presented at the PSA annual conference, London, April 18-21, 2011.

Childs, S., and P. Cowley. "Too Spineless to Rebel? New Labour's Women MPs." British Journal of Political Science 33, no. 3 (2003): 345-365. 
Cowley, P. Revolts and Rebellions: Parliamentary Voting Under Blair. London: Politico's, 2002.

Cowley, P., and M. Stuart. 2005. "Dissension Amongst the Parliamentary Labour Party, 2001-2005: A Data Handbook." Accessed August 10, 2011. http://www.revolts.co. uk/DissensionamongstthePLP.pdf

Cowley, P., and M. Stuart. 2007. "Dave's Dissidents? The Conservative Parliamentary Party in the 2005 Parliament." Accessed August 10, 2011. http://www.revolts.co.uk/Daves\% 20Dissidents\%2005-07.pdf

Crowe, E. "The Web of Authority: Party Loyalty and Social Control in the British House of Commons." Legislative Studies Quarterly 11, no. 2 (1986): 161-185.

Evans, P. Dod's Handbook of House of Commons Procedure. 7th ed. London: Dod's, 2009.

Hay, C. The Political Economy of New Labour: Labouring Under False Pretences. Manchester: Manchester University Press, 1999.

HC 290. First Report From the Select Committee on Procedure: Conduct of Members in the Chamber and the Alleged Abuse of Parliamentary Privilege. London: HMSO, 198889.

Hetherington, A., K. Weaver, and M. Ryle. Cameras in the Commons. London: Hansard Society, 1990.

House of Commons Information Office. 2010. "Broadcasting Proceedings of the House, Factsheet G5.” http://www.parliament.uk/documents/commons-information-office/ g05.pdf

House of Commons Library Research Paper 09/31. 2009. "Members Since 1979.” www. parliament.uk/briefing-papers/RP09-31.pdf

Jennings, I. Parliament. Cambridge: Cambridge University Press, 1957.

Judge, D. "Disorder in the House of Commons." Public Law (Autumn 1985): 368-376.

Judge, D. "Disorder in the 'Frustration' Parliaments of Thatcherite Britain." Political Studies 40, no. 3 (1992): 532-553.

Kerr, P. Post-War British Politics: From Conflict to Consensus. London: Routledge, 2001.

King, O. The Oona King Diaries: House Music. London: Bloomsbury, 2007.

Lovenduski, J. Feminizing Politics. Cambridge: Polity Press, 2005.

Lovenduski, J. "Prime Minister's Questions as Political Ritual." British Politics 7, no. 4 (2012): 314-340.

Lowther, E. "Do We Really Hate MPs Getting Rowdy?", February 5, 2013. Accessed on BBC News website, February 6, 2013. http://www.bbc.co.uk/news/uk-politics21263704

McDougall, L. Westminster Women. London: Vintage, 1998.

Moncrief, C. Wine, Women and Westminster. London: JR Books, 2008.

Mullin, C. Decline and Fall. London: Profile, 2010.

Norton, P, ed. The Conservative Party. Michigan: Prentice Hall, 1996.

Norton, P. "Playing by the Rules: The Constraining Hand of Parliamentary Procedure." Journal of Legislative Studies 7, no. 3 (2001): 13-33.

Puwar, N. Space Invaders: Race, Gender and Bodies Out of Place. London: Berg, 2004.

Radice, L., E. Vallance, and V. Willis. Member of Parliament: The Job of a Backbencher. Basingstoke: Macmillan, 1986.

Rush, M. The Role of the Member of Parliament Since 1868: From Gentlemen to Players. Oxford: OUP, 2001.

Searing, D. Westminster's World: Understanding Political Roles. Harvard: Harvard University Press, 1994.

Sones, B., M. Moran, and J. Lovenduski. Women in Parliament: The New Suffragettes. London: Politicos, 2005.

Speaker's Conference. Speaker's Conference on Parliamentary Representation Final Report. London: TSO, 2010. 
Stevenson, A. "Does the Speaker have a (Parliamentary) Death Wish?." www.politics.co.uk, 14 July 2011. Accessed November 16, 2011. http://www.politics.co.uk/commentanalysis/2011/07/14/comment-does-the-speaker-have-a-parliamentary

Thomas, G. Mr Speaker: The Memoirs of Viscount Tonypandy. London: Century, 1985.

Uslaner, E. "Comity in Context: Confrontation in Historical Perspective." British Journal of Political Science 21, no. 1 (1991): 45-77.

Waller, R., and B. Criddle. An Almanac of British Politics. 8th ed. London: Routledge, 2007.

Wolfe, E. "Creating Democracy's Good Losers: The Rise, Fall and Return of Parliamentary Disorder in Post-war Japan." Government and Opposition 39, no. 1 (2004): 55-79.

Wright, T. British Politics: A Very Short Introduction. Oxford: OUP, 2003. 